http://heanoti.com/index.php/hn

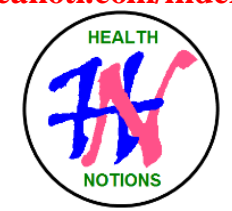

RESEARCH ARTICLE

URL of this article: http://heanoti.com/index.php/hn/article/view/hn30113

\title{
Analysis of Maternal Mortality Due to Hypertension in Pregnancy in West Bandung
}

\author{
Karwati $^{1(\mathrm{CA})}$, Wiryawan Permadi², Dewi M.D. Herawati ${ }^{3}$ \\ ${ }^{1(\mathrm{CA})}$ Institute of Health Sciences "Budi Luhur" Cimahi; karwatidk@gmail.com (Corresponding Author) \\ ${ }^{2}$ Postgraduate School, Universitas Padjadjaran Bandung; wiryawan_permadi@yahoo.com \\ ${ }^{3}$ Postgraduate School, Universitas Padjadjaran Bandung; dewimdh@yahoo.com
}

\begin{abstract}
Hypertension in pregnancy is one of causes in maternal mortality in West Bandung District in 2017 and there are 11 mothers (39.28\%) of 28 mortality cases, which is in the highest rank. Moreover, this research aimed at analyzing maternal mortality due to hypertension in pregnancy in West Bandung District. This research was qualitative research by utilizing grounded theory approach with constructivism paradigm. Sample of this research was the closest family and health personnels who knew the cronology of maternal mortality and there were 21 people from 8 mortality cases. The sample collection utilized purposive sampling technique. Meanwhile, the instruments of this research were researchers, interview guidance, stationery, and voice recorder. Validity test utilized triangulation technique. Technique of data collection was by in depth interview and the analysis process were by transcription, reduction, coding, categorization, and theme. The result of this research was known that factors, which had contribution against maternal mortality, was such as poor access of health service and it was caused by several things: PONED function that had not been optimal in handling hypertension in pregnancy, poor quality of health service, guidance in handling hypertension in pregnancy that had not been optimal, less optimal information from health service, health personnel's poor knowledge about hypertension in pregnancy, and delay in referring to hospital. The next factor was unhealthy living behavior, such as mother who had risk of hypertension in pregnancy did not use long-term contraception, underwent quite high failure level in the use of long-term contraception, the mother was a missing patient from the referral, and not sensitive against emergency situation. Besides that, unknown or unexpected factors also became contribution against mortality, such as unclear demographic status; undesirable pregnancy; assuming that dying in pregnancy, having birth, and in postpartum period was martyred. In conclusion, factors that contributed against maternal mortality due to hypertension in pregnancy in West Bandung District were access of health service, healthy living behavior, and unknown even unexpected factors. However, the factors that really impacted against maternal mortality were access of health service and healthy living behavior.
\end{abstract}

Keywords: Maternal mortality, Hypertension in pregnancy

\section{INTRODUCTION}

\section{Background}

Maternal mortality is a complex problem that does not only give an impact for women but also for family and society. One of causes of maternal mortality is hypertension in pregnancy that is occurred because or while being pregnant and can influence the pregnancy itself or as a cause of pregnancy and will be over in postpartum period with blood pressure in $>140 / 90 \mathrm{mmHg}$. If there has no history of suffering hypertension before, Hypertension in Pregnancy was usually occurred in gestational age in 20 weeks. ${ }^{(1),(2)}$ This can cause mortality for the mother and the baby who will be born. In 2017 in West Bandung District, total of maternal mortality was around 28 maternal mortality who were spread to several areas of Public Health Centers. Moreover, one of causes of maternal mortality was hypertension in pregnancy and it placed the highest rank which there were 11 mothers $(39.28 \%)^{(3)}$ 


\section{Purpose}

This research aimed at analyzing maternal mortality that was caused by hypertension in pregnancy in West Bandung District.

\section{METHODS}

This study was a qualitative research by using grounded theory approach with constructivism paradigm. The sample of this research was the closest family and health personnels who knew the cronology of maternal mortality and there were 21 people from 8 mortality cases. Technique of sample collection was by purposive sampling. Meanwhile, the research instruments were researchers, interview guidance, stationery, and voice recorder and the validity test was using triangulation technique. Technique of data collection was by in depth interview. The analysis process were by transcription, reduction, coding, categorization, and theme. ${ }^{(4),(5)}$

\section{RESULTS}

The maternal mortality due to Hypertension in Pregnancy in West Bandung District could be categorized as preventable mortality. This maternal mortality could be based on several factors, which were health status (nutrition, infection, chronic disease, complication history), reproduction status (age, parity, marital status), access of health service (location of health service, the scope of health service, quality of health service, access of information about health service), healthy living behavior (contraception use, antenatal examination, chilbirth help), and unknown or unexpected factors.

Table 1. Characteristic of maternal mortality due to hypertension in pregnancy

\begin{tabular}{|c|c|}
\hline Variable & $\mathrm{n}=8$ \\
\hline \multicolumn{2}{|l|}{ Mortality Period } \\
\hline Pregnancy & $2(25 \%)$ \\
\hline Childbirth & $2(25 \%)$ \\
\hline \multicolumn{2}{|l|}{ After Childbirth } \\
\hline \multicolumn{2}{|l|}{ Postpartum } \\
\hline \multicolumn{2}{|c|}{ Types of Hypertension in Pregnancy } \\
\hline Gestational Hypertension & $2(25 \%)$ \\
\hline PEB & $3(37.5 \%)$ \\
\hline Eclampsia & $3(37.5 \%)$ \\
\hline Chronic Hypertension & $0(0 \%)$ \\
\hline Superimposed Preeclampsia & $0(0 \%)$ \\
\hline \multicolumn{2}{|l|}{ Age (year) } \\
\hline Mean+STD & $30.63 \pm 7.050$ \\
\hline Median & 32.00 \\
\hline Range (min-max) & $20-39$ \\
\hline \multicolumn{2}{|l|}{ Parity } \\
\hline 1 & $1(12.5 \%)$ \\
\hline 2 & $3(37.5 \%)$ \\
\hline 3 & $1(12,5 \%)$ \\
\hline 4 & $3(37.5 \%)$ \\
\hline \multicolumn{2}{|l|}{ Gestational Age (weeks) } \\
\hline Mean+STD & $35.50 \pm 5.099$ \\
\hline Median & 37.50 \\
\hline Range (min-max) & $26-40$ \\
\hline \multicolumn{2}{|c|}{ Gestational Age while being Found Hypertension in Pregnancy (weeks) } \\
\hline Mean+STD & $26.83 \pm 13.060$ \\
\hline Median & 27.00 \\
\hline Range (min-max) & $20-39$ \\
\hline
\end{tabular}




\begin{tabular}{|c|c|}
\hline Variable & $\mathrm{n}=8$ \\
\hline \multicolumn{2}{|l|}{ Occupation } \\
\hline Jobless & $6(75 \%)$ \\
\hline Private Employees & $2(25 \%)$ \\
\hline \multicolumn{2}{|l|}{ Disease History } \\
\hline No & $4(50 \%)$ \\
\hline Heart Disease & $1(12.5 \%)$ \\
\hline Hypertension & $2(25 \%)$ \\
\hline Epilepsy & $1(12.5 \%)$ \\
\hline \multicolumn{2}{|l|}{ Childbirth Place/ Mortality Place } \\
\hline Hospital & $6(75 \%)$ \\
\hline Midwife Private Practice (Bidan Praktek Swasta-BPS) & $1(12.5 \%)$ \\
\hline House & $1(12.5 \%)$ \\
\hline \multicolumn{2}{|l|}{ Mileage to Referral Place (KM) } \\
\hline Mean+STD & $29.75 \pm 34.475$ \\
\hline Median & 12.50 \\
\hline Range (min-max) & $1-100$ \\
\hline \multicolumn{2}{|l|}{ Duration to Referral Place (Minutes) } \\
\hline Mean+STD & $78.13 \pm 60.883$ \\
\hline Median & 60.00 \\
\hline Range (min-max) & $15-210$ \\
\hline \multicolumn{2}{|l|}{ Duration in Waiting for Having Help in Referral Place (Minutes) } \\
\hline Mean+STD & $27.75 \pm 23.144$ \\
\hline Median & 23.00 \\
\hline Range (min-max) & $5-60$ \\
\hline \multicolumn{2}{|l|}{ Mortality Time Period (Hours) } \\
\hline Mean+STD & $49.5271 \pm 116.9$ \\
\hline Median & 2.7917 \\
\hline Range (min-max) & $0.75-337.18$ \\
\hline \multicolumn{2}{|l|}{ Characteristic of Referral } \\
\hline Direct & $3(50 \%)$ \\
\hline Indirect & $3(50 \%)$ \\
\hline \multicolumn{2}{|l|}{ Examination place for Antenatal Care (ANC) } \\
\hline Midwife Private Practice (BPS) & $3(37.5 \%)$ \\
\hline Midwife Private Practice (BPS) and Public Health Center & $2(25.0 \%)$ \\
\hline Midwife Private Practice (BPS) and Private Clinic & $3(37.5 \%)$ \\
\hline \multicolumn{2}{|l|}{ Caregiver for Antenatal Care (ANC) } \\
\hline Midwife & $5(62.5 \%)$ \\
\hline Midwife and doctor & $3(37.5 \%)$ \\
\hline \multicolumn{2}{|l|}{ Total of Antenatal Care (ANC) Examination } \\
\hline Mean+STD & $8.88 \pm 5.357$ \\
\hline Median & 9.50 \\
\hline Range (min-max) & $3-18$ \\
\hline \multicolumn{2}{|l|}{ Helper in Referral Place } \\
\hline Doctor & $6(75.0 \%)$ \\
\hline Midwife & $2(25.0 \%)$ \\
\hline \multicolumn{2}{|l|}{ First Helper } \\
\hline Midwife & $8(100 \%)$ \\
\hline
\end{tabular}


From table 1, maternal mortality in 8 cases showed that mortality period in pregnancy period was in 2 $(25 \%)$, in childbirth period was in $2(25 \%)$, after childbirth was in $2(25 \%)$, and in postpartum period was in 2 $(25 \%)$.

Types of hypertension in pregnancy that was found in 8 mortality cases were 3 types, which were gestational hypertension in $2(25 \%)$, PEB in $3(37.5 \%)$, and eclampsia in $3(37.5 \%)$.

The average of mother's age was $30.63 \pm 7.050$, which the minimum age was 20 years old and the maximum age was 39 years old. In the maternal parity, it was obtained the data which showed the most number was having parity in two and four (37.5\%), meanwhile, the smallest one was having parity in one and three (12.5\%). Besides, the latest gestational age was about 35.50 \pm 5.099 , which the minimum gestational age was 26 weeks and the maximum gestational age was 40 weeks. Meanwhile, the gestational age when it was found hypertension in pregnancy had average in $6.83 \pm 13.060$, which the minimum gestational age was 4 weeks and the maximum gestational age when it was found hypertension in pregnancy was 40 weeks.

In variable of occupation, most of mother who did not have any jobs were 6 mothers $(75 \%)$, and the mothers who were private employees were 2 mothers $(25 \%)$, meanwhile in variable of disease history, most of mothers had no disease history $(50 \%)$, and the mother who had heart disease history was 1 mother (12.5\%) and epilepsy was also 1 mother $(12.5 \%)$.

From the table 1, it was obtained that most of childbirth place/ maternal mortality place due to hypertension in pregnancy was in hospital (75\%), and only $12.5 \%$ was in Midwife Private Practice and 1 mother (12.5\%) was in house. The average mileage to referral place was $29.75 \pm 34.475$, which the closest distance range was $1 \mathrm{~km}$ and the farthest one was $100 \mathrm{~km}$, meanwhile, the average of duration to referral place was $78.13 \pm 60.883$, which the fastest duration was 15 minutes and the longest one was 210 minutes. After the pregnant mother arrived in the referral place, duration of waiting time to have medical help was about $27.75 \pm 23.144$ minutes, which the fastest time was 5 minutes and the longest one was 60 minutes. Thus, it had period of mortality time from handling in first place was in the average of $29.5271 \pm 116.9$ hours, which the fastest duration was 0.75 hour and the longest one was 337.18 hours. Meanwhile, the characteristic from the referral was obtained that $50 \%$ was directly referred and $50 \%$ was indirectly referred.

In addition, from table 1 , it was also obtained the result that based on the examination place of antenatal care (ANC), all of the mothers (100\%) had checked their pregnancy to health service, which 3 mothers $(37.5 \%)$ checked the ANC to Midwife Private Practice, 3 mothers (37.5\%) checked it to Midwife Private Practice (BPS) and private clinic, and 2 mothers $(25 \%)$ checked to Midwife Private Practice and Public Health Center. While, caregivers for ANC, all of them (100\%) were health personnels, who most of them were midwives $62.5 \%$, and others were midwives and doctors $(37.5 \%)$. Total of ANC examination who examined the pregnancy was in the average of $8.88 \pm 5.357$, which it was about 3 times until 18 times and the helpers in the referral place, who were most of them were doctors $(75 \%)$ and the others were midwives $(25 \%)$, and the helper for all pregnant mothers firstly was midwife $(100 \%)$ before being referred.

However, there was indirect cause or contributor that influenced mortality due to this hypertension in pregnancy, such as access of health service that was influenced by one of the existance of Comprehensive Emergency Obstetric Neonatal Care (PONEK)/ Basic Emergency Neonatal Obstetric Care (PONED) in West Bandung District. Moreover, from the interview result, it was obtained that most of the function of Basic Emergency Neonatal Obstetric Care, which was as the best line for either antenatal care service, childbirth care, postpartum care, or even for handling emergency in West Bandung area, had not been optimal in decreasing maternal mortality due to this hypertension in pregnancy. The function of PONED that was not optimal, was influenced by several factors, which were doctor who had a job in PONED was still on call system; doctor still had not been able to standbye in PONED because being assigned to other health places; the health personnels in PONED were still in less number; and there had not been any agreement among the health personnels in handling hypertension in pregnancy, hence, it was often occurred difference in giving opinion between them. Moreover, due to this different opinion, finally, there were still many health personnels who did not do their job based on the function.

The beginning treatment as a prevention of spasm for the mother with hypertension in pregnancy in health facility had not been appropriate with clinical pathway in handling hypertension in pregnancy. Nine informants said that after being conducted examination and it was known that the mother had high blood pressure and positive urine protein, the next step was being referred directly without any prevention treatment of spasm before. Several midwives did not give any reason of why they did not do any prevention treatment of spasm for hypertension in pregnancy, such as giving $\mathrm{MgSO}_{4}$. However, there were also several midwives who gave the reason of why they did not do it. The reasons were different, such as because it was not midwife's authority to inject MgSO4. Because there was not any patient's family who accompanied or had responsibility for the patient and her blood pressure had been high. That was why the patient was not given $\mathrm{MgSO}_{4}$. This was also because the midwife was afraid of giving it and afraid of being blamed by the family if finally later, the patient died after being conducted the medical 
action. Another phenomena that the midwife did not give $\mathrm{MgSO}_{4}$ because not all health personnels had emergency medicine, whereas, it was given or socialized that the midwife must have / provide emergency medicine, such as $\mathrm{MgSO}_{4}$ when she conducted private practice. However, in fact that there were still several midwives who did not provide it, hence, giving $\mathrm{MgSO}_{4}$ that was as a prevention treatment for spasm was not appropriate with her authority. Thus, when the pregnant mother arrived at referral place, she had been unstable condition.

Clinical pathway in handling hypertension in pregnancy in either BPM or hospital was still different because the guidance in handling hypertension in pregnancy had not been optimal. Several informants siad that all this time, clinical pathway in handling hypertension in pregnancy between one doctor to the other doctors was still different. However, it would be better if there was a similar standard guidance in handling hypertension in pregnancy in all of health services and the result would be better than clinical pathway.

In conducting emergency help, health personnels still had several lacks and limitations, such as health personnels were considered careless and less professional in conducting medical action by the patient's family as if the health personnels only wanted to try to handle childbirth process in the place, which the patient should be conducted referral as soon as possible when the patient was in stable condition.

According to the access of health service, most of childbirth place or maternal mortality place was in hospital with the most number of helper was a doctor. Most of pregnant mothers did not experience difficulty for referring in transpostation side and mileage side. Although there was not any obstacles in doing referral, most of informants said that there was still a delay in referring. Moreover, many factors that influenced a delay in referral, thus, the pregnant mother was also late to be treated in the referral place. When the pregnant mother arrived in referral place, she had been in unstable condition and most of the pregnant mothers experienced this case. All in all, the first delay was a delay in making decision.

Based on the result of in depth interview that was conducted in this research, it was obtained the information that when it was occurred an emergency, a decision-making was still based on the culture "discussing", that had impact in delay of referring. The role of husband who was as a decision-maker whether his wife should be referred soon or not, and his wife was delayed to be referred because the husband was not in that place with his wife. While, the family did not accompany/ deliver the pregnant mother to go to midwife's place, thus, the difficulty in decision-making, such as waiting the decision-maker came who was usually the husband or someone who would pay all costs was still felt as the cause of delay in referring. A delay was also occurred as an impact of either mother's ignorance or family's ignorance regarding dangerous signs that must have a treatment soon to prevent maternal mortality.

In hypertension in pregnancy case, the patient was still looked as usual and there was not any emergency signs that threatened patient's life. However, in any time, it could be occurred more serious condition if the mother was not handled as soon as possible. Most of the family and pregnant mother did not know what hypertension in pregnancy was, either for the cause factors, the symptoms of hypertension in pregnancy, or the preventing and handling hypertension in pregnancy, hence, the pregnant mother and family did not feel any emergency that threatened mother's life. This was caused by mother's and family's knowledge about hypertension in pregnancy was less and it was caused by the information/ health education was less complete and the use of KIA-book (maternal and child health handbook) also had not been optimal.

Gradual referral system enabled the patient was late in having medical treatment. Besides, the capacity of bedroom in the hospital was also limited that enabled the patient to be moved again to several hospitals where were available for the bedroom and this would make the mother's condition more serious and would threaten mother's life. The pregnant mother who did not want to be referred when she was diagnosed hypertension in pregnancy for the first time or when it was found an emergency was also a factor that caused the mother was late to be handled and in other words, she was late in referring to hospital. Furthermore, there was still pregnant mother who was conducted medical treatment in Midwife Private Practice / Birth Clinic firstly before being referred to hospital, which meant that it was not only done first treatment in preventing spasm on preeclampsia , then, she was referred directly,but she was done an inpatient until one day firstly, then, when the pregnant mother was unstable, she would be referred. Besides that, there was also in the clinic to have inpatient for waiting for operation schedule in the next day. In Midwife Private Practice, the pregnant mother was not indirectly referred after having examination, but the pregnant mother was tried to be born in the midwife's house. Thus, after the pregnant mother's condition was worse, it would be conducted spasm treatment and the pregnant mother was planned to be referred to hospital. Hence, the impact that was occurred when the pregnant mother arrived at the referral hospital, she was in unstable condition even before being referred, she was in passing away.

From the research result, $100 \%$ of first helper for pregnant mother was midwife. The midwife was as a first actor in giving health education and she was expected to be able to give health information optimally, particularly for hypertension in pregnancy. However, it was often found several obstacles, such as the people were still difficult or did not want to come if there was a health education or training in health service place or integrated service post (Posyandu). Health personnel's knowledge as a health counselor was important for increasing society's knowledge, particularly for mothers in identifying and preventing hypertension in pregnancy, and also could act faster and correctly if there was an emergency. Based on the interview result from several health personnels, it 
could be concluded that health personnel's knowledge about hypertension in pregnancy: the types of hypertension in pregnancy, risk factors, symptoms, prevention, medical treatment and handling hypertension in pregnancy was still less.

Contraception program had important role in preventing maternal mortality. By using contraception tools, a mother would be able to plan a pregnancy, thus, she could avoid the pregnancy in certain age (too young age or too old age) that also could decrease undesirable pregnancy. Thus, it decreased mortality due to hypertension in pregnancy that was caused by risk factor. Moreover, $50 \%$ from mothers who were in risk category to be pregnant again, they preferred more to use long-term contraception and IUD and MOW,but in fact that they still had a failure in its use, hence, it was occurred the last pregnancy that indirectly increased the list of mother who had high risk against hypertension in pregnancy.

From the result of this research, it was still obtained that health personnels who did not do diagnosis enforcement action for ensuring whether the mothers really underwent preeclampsia or not and this would cause unclear diagnosis, and also finally, the mother was late in identifying and handling hypertension in pregnancy that caused a delay for referring to hospital and the worst cause was maternal mortality.

In the process of data collection through either OVM document, interview, or observation by looking at the medical records in hospital, the researchers found that several mothers when were diagnosed hypertension in pregnancy did not follow as soon as possible of what the health personnels had said for doing referral as further medical examination. Assuming that when the mother had not been inpartu, it would be useless if she was referred to hospital. This was enabled because the health personnels did not accompany or monitor her, thus, the pregnant mother was a missing patient to check her further pregnancy to referral hospital or other health services.

As we know that noone had not been known the exact cause of hypertension in pregnancy and hypertension in pregnancy could be occurred from several risk factors. Although the pregnant mother was free from the risk factor of HDK, which she had done a pregnancy care based on the standard, she was from good background family, she had good access to go to health service, but there was still mortality. This was probably influenced by unknown / unexpected factor, which was indirect factors in maternal mortality due to hypertension in pregnancy that was found by researcher, such as assuming that mortality was a God's will that could not be avoided and assuming that the pregnant mother who died in pregnant condition, childbirth, or postpartum period was martyred. The other factors were the researchers found that psychological factors and dietary habits from several mothers did not undergo significant change. The psychological factors were such as over anxiety; over thought when in pregnancy; pregnant mother's closed attitude that enabled the mother could not think clearly in solving the problem; unclear demographic status; and undesirable pregnancy. Even, there was a pregnant woman who suddenly had high blood pressure after hearing that she would be divorced by her husband and the husband had left her alone when she was pregnant, meanwhile, she must manage her household by self, must earn a living and she became a backbone of the family.

\section{DISCUSSION}

In terms of health service access, in addition to a service location (childbirth place/ mortality place, duration to referral place, and mileage to referral place), other factors that contributed to indirect maternal mortality, including the functions of PONED (Basic Emergency Neonatal Obstetric Services) and PONEK (Comprehensive Neonatal Obstetric Services). From the results of in-depth interviews with several informants, it was found that the function of PONED was not optimal. This could be seen from less number of medical personnel at PONED that made them to take medical personnel from Public Health Center, which actually they had already had quite many jobs, thus, they had to share their jobs. In addition to the lack of human resources, PONED doctor was still on call system that made it difficult for PONED personnel if there was an emergency and the waiting time for pregnant women would be longer before getting doctor's help.

The handling of hypertension in pregnancy cases in PONED had misunderstanding among health personnel. Therefore, there would be unsynchronized working relations hypertension in pregnancy among the personnels and it was unclear about who did what and how to do due to the disagreement. Unlike the function of PONEK, it was said that there were optimal and unoptimal PONEK. The unoptimal here meant that some Public Helath Centers in West Bandung District area did not have PONEK facility and the function had not been good, and most hospitals in West Bandung District area were still in type D, thus, the development of PONEK had not been optimal. Furthermore, PONEK which was already optimal was mostly found in referral hospitals where were in the outside of West Bandung District.

In carrying out the role and function, the quality of health personnels was deficient and the results showed that there were still differences in hypertension in pregnancy diagnoses. Late hypertension in pregnancy diagnosis was because of incomplete diagnosis or even was not done by some midwives. This result was in accordance with Destariani's (2011) cit. Artati Eka (2014) with the title of factors correlated with country midwife's performances in the pre-eclampsia/ eclampsia early detection. The study found that there was a significant correlation between 
knowledge and performance of country midwives in early detection of child irth with severe preeclampsia/ eclampsia cases. ${ }^{(6)}$

The results of this study also showed that different clinical pathways for hypertension in pregnancy treatment among doctors were caused by unoptimal hypertension in pregnancy guidelines. If there was an optimal guideline, all health personnels would understand the implementation of hypertension in pregnancy treatment well. There were still many health service places where did not put clinical pathways in a visible place or position.

There were still health personnels who did not carry out the initial treatment to prevent spasm in hypertension in pregnancy and this was due to several reasons; the authority that did not allow giving $\mathrm{MgSO}_{4}$ in emergency conditions before referral process and there were midwives who did not provide emergency medicines. However, this was not in accordance with Indonesian Minister of Health Regulation Number 28 in 2017 part Two article 19 paragraph 3 letter d, about emergency medicine, other drugs in drug requirements, disposable medicine permitted, and midwivery practices, which mentioned that in providing maternal health services, midwives were authorized to handle emergency followed by referral as well as drugs that had to be provided for emergency, including $40 \%$ of $\mathrm{MgSO}_{4} \cdot{ }^{(7)}$

It was needed an understanding between policy makers and health personnels on service providers about the authority to handle hypertension in pregnancy. The socialization of the authority had to be carried out and the clinical pathway needed to be reformed, therefore, guidelines for handling hypertension in pregnancy were clear and common among health personnels.

Another obstacle was the absence of family to accompany the patient, thus, none gave medical approvals and health personnels were afraid of being blamed if something undesirable happened to pregnant women. This was in accordance with Kusuma, Affandi, Ocviyanti, and Prihantini's study in 2009 which found that the performance of nurses and midwives were still lack in handling severe preeclampsia/ eclampsia. Knowledge through the sense system, such as eyes and ears, through health education and training were needed in handling severe preeclampsia/ eclampsia in order to improve the accuracy of midwives. ${ }^{(6)}$

There was a need of health education about hypertension in pregnancy risk on maternal mortality and it was expected that families could take pregnant women to health care facilities and accompany them, therefore, the medical treatment that would be given to them would be faster and the family could also be responsible for pregnant women morally and materially.

The results of in-depth interviews was obtained that registration of BPJS (Social Assurance Administrator) for pregnant women was still complicated due to incomplete administrative requirements. This study was in accordance with Ignasius Luti's research entitled local government policy in improving the health referral system by interview method. It was obtained that there were many citizens who did not have ID cards and other administrative cards. Residents who had not received the card came from remote areas even though they still received health insurance borne by the regional and central government. ${ }^{(6)}$

The results found delays in referrals even though transportation was not an obstacle in referrals. There were factors influencing delays in referring, those were delays in decision making, being late in reaching the referral place and being late to be handled. The most frequent factor was delay in decision making from pregnant women as well as from health personnels. Delay in decision making from patients was caused by the absence of patient's family, sudden BPJS cards making, waiting for the decision-maker of the family or waiting for the husband's decision. Late recognizing of hypertension in pregnancy risk was also caused by lack knowledge of pregnant women/ families due to the lack provision of information/ counseling by health personnels. Late recognizing of hypertension in pregnancy was due to a diagnosis that was not done or incomplete diagnosis and the possibility of lack knowledge of health personnel.

Knowledge was a predispsising factor that could affect a person's behavior towards better decision making. Knowledge was considered good if someone made right decision that correlated to the problem that was faced, but those who had lack knowledge would take the opposite decision. The level of education and sources of information that was received by people would affect people's knowledge. In this case, it was the knowledge of hypertension in pregnancy risk. Knowledge was expected to be a reference in every health attitude and behavior in decision making. ${ }^{(8)}$

The research by Relics, Kandau and Pangemanan about mothers' decision analysis in choosing birth attendants by in-depth interviews was obtained that the knowledge about mother's health of pregnancy and childbirth who gave birth by the help from traditional birth attendants (dukun bayi) was less rather than mother who gave birth by the help from health personnel (midwives). ${ }^{(8)}$ It was in line with the result of this study.

The results of this study was also in accordance with Destariani's (2011) cit. Artati Eka (2014) with the title of factors that correlated with the performance of country midwives in early detection of preeclampsia/ eclampsia. It was stated that there was a correlation between midwives' knowledge and midwives' performance in early detection of severe preeclampsia/ eclampsia cases. ${ }^{(6)}$

The cause of late handling were the rejection of referral by pregnant women, gradual referral system and waiting time to be handled. Another cause was being late to reach the referral hospital, possibly due to the distance and duration time. 
Health behaviors included contraceptive usage behavior, in which mothers who participated in family planning programs would give birth less frequently rather than mothers who did not participate in family planning. Some women with high risk of hypertension in pregnancy said that most of them were failed in using long-term contraception, including IUD and Female Operative Method. This would increase the list of mothers with high risk of developing hypertension in pregnancy.

The behavior of antenatal examination in which mothers who regularly conducted antenatal examinations would be detected their health problems and complications, birth attendants; in which mothers who were assisted by traditional birth attendants (dukun bayi) had greater risk of dying rather than mothers who were assisted by health personnels (such as midwives), as well as maternity places, where having childbirth at home would hinder access to get referral services quickly if it was needed at any time.

From table 1, it was found that based on ANC examination, all mothers (100\%) had checked their pregnancy in health care facilities, those were 3 people $(37.5 \%)$ who checked their ANC to Midwife Private Practice (BPS), 3 people (37.5\%) to BPS and private clinics, and 2 people (25\%) to BPS and Public Health Center, while all providers $(100 \%)$ were health personnels and those were 5 Midwives $(62.5 \%)$ and 3 doctors $(37.5 \%)$.

Most mother checked her pregnancy at $8.88 \pm 5.357$ during pregnancy with a range between 3 times and 18 times, this was in accordance with the standard of antenatal care to avoid the risk of complications in pregnancy and childbirth, every mother was required to check her pregnancy at health facility by health personnels, both doctors and midwives as health providers with minimum of 4 times during pregnancy, once in the first trimester, once in the second trimester and twice in the third trimester, including at least once accompanied by a husband or family. In addition, it was recommended for pregnant women to check their pregnancy to the doctor at least once to detect medical disorders generally. ${ }^{(9)}$

The results of this study were in accordance with Arulita's (2007) which showed that factors affecting maternal mortality with the greatest cause of hypertension in pregnancy was occurred in mothers with good antenatal examination $>4$ times during pregnancy by $69.2 \%$ while mothers with bad antenatal examinations was $30.8 \%$. Antenatal examinations which were carried out by midwives were 41 cases $(78.9 \%)$ and by doctors and midwives were $17.3 \%$ cases. $^{(10)}$

Table 4.1 showed that the most birth helper in referral place was a doctor in hospital (6 people (75\%)) and the others were midwives ( 2 people $(25 \%)$ ). In this case, all mothers had been helped by health personnels, while the first helper before being referred was midwife (100\%).

This was not in accordance with Arulita's (2007) that maternal mortality due to hypertension in pregnancy showed that the first maternal helpers were non-health personnel and health personnel. In the case group, the first helper of non-health personnel was $32.6 \%$ greater rather than in the control group, which was $11.5 \%$. Whereas, the first helper of health personnel was $67.4 \%$ smaller than in the control group which was $88.5 \%$. The first helper of childbirth by health personnels in case group was mostly carried out by midwives (21 cases (45.7\%)) and 10 cases were carried out by doctors in the hospital (21.7\%). In control group, midwives as the first helper were 40 cases $(76.9 \%)$ and 6 cases by doctors in the hospital $(11.6 \%)$. The results of bivariate analysis showed that nonhealth personnel as the first helper had a risk of maternal death 3.7 times greater than mothers who gave birth assisted by health personnels $(\mathrm{OR}=3.7 ; 95 \% \mathrm{CI}: 1.3-10,6)$ and statistically, it was showed a significant correlation of hypertension in pregnancy $(\mathrm{p}=0.011){ }^{(10)}$

From the interview results, it was found that midwife as the first helper before referring was still unoptimal in carrying out their duties due to several reasons both from the midwives themselves and from pregnant women/ families. Diagnosis had not been carried out by midwives, then, this would lead to a different diagnosis between midwives and referral hospitals. This would take longer time of handling at referral hospital because it should have supporting results to establish a diagnosis, thus, the hospital just continued, but in this case, it needed additional time to do urine protein examination first.

This was also in accordance with Destariani's (2011) cit. Artati Eka (2014) by the title of factors that correlated with the performance of country midwives in pre-eclampsia/ eclampsia early detection showed that there was a correlation between midwife's knowledge and performance in early detection of severe preeclampsia/ eclampsia cases. ${ }^{(6)}$

Inadequate referral requirements included the absence of health personnels in accompanying pregnant mother to referral place, especially for pregnant women who had not yet entered inpartu time, it was possible that pregnant women would be absent from referral because there were also found pregnant women who did not go directly to the referral place. Health personnels did not include referral letters at the time of referral; this was proven by the absence of a referral letter that was attached to patient's maternal verbal autopsy even though the health organization had socialized pre-referral form that had to be made by health personnels before referring. In the pre-referral form, there were patient's diagnosis and action that had been taken. The absence of a companion and referral letter made some patients did not implement the advice of health personnel as what was shown in table 4.5 that maternal mortality due to hypertension in pregnancy were $50 \%$ of the mothers who were immediately referred and $50 \%$ of mothers who were not directly referred by the family. If referral was due to obstetric or 
childbirth problem, it should be midwife who had to accompany during the referral process and was completed by a referral letter.

The presence of health personnel assistance had benefits in reducing the level of morbidity and mortality. Conducted study by Ignasius Luti, et al, about local government policy in improving health referral system in archipelago area, showed that all patients/ communities who were referred were accompanied by nurses/ midwives and it was not only done for patients with certain guarantees but also for all patients who came from Regional Health Assurance and Public Health Assurance. The assisted personnel were midwives/ nurses depending on health problems which were suffered by patients. ${ }^{(11)}$

The results showed that $50 \%$ of pregnant women were not immediately referred/ were absent to this referral because pregnant women/ families were not sensitive to emergency condition that was happened and considered that it was a mediocre thing. Nevertheless, this was due to lack knowledge of pregnant women/ families.

The absence of midwife in referral due to the fact that pregnant mother had not been in inpartu, some midwives said that they were afraid of being blamed by the family because of the family's absence, thus, there were no decision maker about this referral. Another reason was the lack of health personnels, therefore, if midwife or health personnel accompanied the pregnant mother, there would be no one would handle other patients.

In order to avoid pregnant women who were not doing what was recommended by health personnel, the pregnant women should be accompanied to referral places and should get medical treatment although they had been in inpartu or not. There should be an agreement between the director of the workplace or government about duties and responsibilities of health personnels as public servants, especially midwives who practically had to be 24 hours ready to receive maternity patients. Thus, the health personnels, especially midwives, could carry out their duties thoroughly.

An important fact that pregnancy complications could arise from a variety of other factors rather than just from a lack of access to health services, low health condition before or during pregnancy, or woman's reproductive status. Women with good family's backgrounds, having good access to the best quality of health services (including prenatal care), and having good health before pregnancy could still experience serious obstetric complications that could not be explained or predicted.

A recent study at a non-hospital maternity center in the U.S. showed that nearly 12,000 women who had health checks at basic service centers for prenatal care, $15 \%$ were referred to hospitals because they were thought to be at high risk. While those who were referred to the hospital on inpartu time were those who were with low risk and had an average of 11 prenatal visits.

Despite having intensive screening and prenatal care, nearly $8 \%$ of these women experienced serious maternal and fetal complications. In developing countries, predictions of obstetric complications were usually difficult. For example, although a poor obstetric history was known and predicted to experience obstructive childbirth, a study in Zaire found that only $29 \%$ of obstructive childbirth cases were predictable based on obstetric history. The remaining $71 \%$ of cases was occured in women with no risk factors. ${ }^{(12)}$

From the interviews, researchers found that some pregnant mothers felt that they did not experience a worrying situation, took care of their pregnancy properly by doing regular checks to doctors and midwives, and maintained their diet, carried out what the midwife or doctor had recommended, such as eating food that was allowed or not allowed, limited their own food to prevent hypertension, but in the fact that the pregnant mother still experienced maternal mortality.

Researchers found possible factors that could not be predicted or unknown indirectly which affected maternal mortality due to hypertension in pregnancy; Pregnant women experienced over anxiety and many thoughts during pregnancy, therefore, it interfered their activities and changed their dietary. This over thinking was usually about whether the childbirth process would be normally or not. Moreover, it was caused by hearing negative information from their environments, patient's characteristic as introvert, and family's difficulty in communicating with pregnant women. Hence, the family could not understand and know what was felt by pregnant women which could be late handling if the pregnant mother experienced something that threatened her life.

The interviews showed that some mothers rarely told complaints and results of midwife's examinations, considered that mortality was a God's will and could not be avoided. In this case, mothers no longer tried to prevent mortality even though midwife as a service provider had explained and recommended to do more intensive examination in hospital. Thus, if something was happened, it could be handled immediately. However, this was not successful because of the pregnant mother's surrender attitude of the God's will. This attitude led to assumption that mother who died during pregnancy, childbirth, and postpartum was martyred and this had become a culture in the community and even it was not questioned if the mother died during pregnancy, childbirth, or postpartum.

Another unexpected factor was undesirable pregnancy due to contraceptive failure, the husband's absence, divorce process, having many children, having toddlers, and the mother was also required to earn a living alone.

Unclear demography also correlated with referral and the financing at hospital was still found. It was an obstacle factor because BPJS financing was aimed for family members with family cards and ID cards of West 
Bandung District. There were still many cases which were found, such as complicated process of receiving patients in hospitals, especially those who had just moved to West Bandung District. Those were possible factors which were unexpected/ unrecognized that indirectly could cause maternal mortality due to hypertension in pregnancy.

\section{CONCLUSION}

Based on the results of the analysis, it could be seen that access to health services, healthy living behavior, and unknown/ unpredictable factors were contributing factors of maternal mortality due to hypertension in pregnancy in West Bandung District. However, factors that had a major influence on maternal mortality were health service access and healthy living behavior, with the following conclusions:

1. Based on access to health services; Besides maternal place, the distance to the referral place, the duration time to referral place, and duration time in waiting for having help, the indirect factor of maternal death due to hypertension in pregnancy was also caused by PONED that had not been functioned optimally in handling HDK. This unoptimal PONED was shown by on call system, less human resources, less harmonious relations between doctor and midwife, and poor quality of health service, including referral letters which were not synchronized, the absence of emergency medicine that was owned by midwives, midwives still thought that handling hypertension in pregnancy was not their authority, and guidelines for handling hypertension in pregnancy were not optimal. Information access about health services was found that the use of MCH (Maternal and Child Health) books was not optimal, the provision of hypertension in pregnancy information was incomplete due to health personnel's lack knowledge in providing information about hypertension in pregnancy and it impacted to; late in decision making, late to reach the referral, and late to be handled.

2. Based on healthy living behavior; not using long-term contraception for mothers with high risk of hypertension in pregnancy, high failure rates in contraceptive usage, the patient's absence from referral that was caused by midwives who did not accompany them to referral places, and pregnant women were not sensitive to emergency situation. In addition, different diagnosis was also a cause of high mortality rate due to hypertension in pregnancy and this was due to diagnosis enforcement that was not carried out by health personnels.

3. Based on unknown or unexpected factors; unclear demography led to difficulty in the management of childbirth costs, undesirable pregnancy affected patient's psychological condition in taking care of their pregnancy, assuming that death during childbirth or pregnancy was martyred, so it impacted no patients were motivated to stay alive and they preferred to surrender to the God's will.

\section{REFERENCES}

1. Radjamuda N, Montolalu A. Factors Related to Hypertension in Pregnant Women (Faktor-Faktor yang Berhubungan dengan Kejadian Hipertensi pada Ibu Hamil. Jurnal Ilmiah Bidan. 2014;2(1):33-45.

2. Rukiyah YA. Midwifery Care IV (Midwifery Pathology) (Asuhan Kebidanan IV [Patologi Kebidanan]). Jakarta: Trams Info Media; 2010.

3. Dinkes-KBB. Health Profile of West Bandung Regency in 2016 (Profil Kesehatan Kabupaten Bandung Barat Tahun 2016). Bandung: Dinkes-KKB; 2016.

4. Alwasilah AC. Basics of Designing and Conducting Qualitative Research (Dasar-Dasar Merancang dan Melakukan Penelitian Kualitatif). Jakarta: Pustaka Jaya; 2009.

5. Bungin B. Qualitative Research (Penelitian Kualitatif). Jakarta: Fajar Interpratama Offset; 2011.

6. Artati ES. Analysis of Determinants Affecting Village Midwives in Referral Compliance in Cases of Preeclampsia / Eclampsia in Banyumas Regency (Analisis Determninan yang Mempengaruhi Bidan Desa dalam Kepatuhan Rujukan pada Kasus Preeklamsia/Eklamsia di Kabupaten Banyumas). Jurnal Ilmiah Kebidanan. Purwokerto. 2014;5(2):16-25.

7. Kemenkes RI. Regulation of the Minister of Health of the Republic of Indonesia Number 28 of 2017 concerning Permit for the Practice of Midwives (Peraturan Menteri Kesehatan Republik Indonesia Nomor 28 Tahun 2017 Tentang Izin Penyelenggaraan Praktik Bidan). Jakarta: Kemenkes RI; 2017.

8. Parenden DR. Analysis of the Decision of Mothers in Choosing Childbirth Helper in Kabila Bone Health Center Area (Analisis Keputusan Ibu Memilih Penolong Persalinan di Wilayah Puskesmas Kabila Bone). JIKMU. 2015;5(2a):362-372.

9. Kemenkes RI. Pocket Book for Maternal Health Services in Basic and Referral Health Facilities (Buku Saku Pelayanan Kesehatan Ibu di Fasilitas Kesehatan Dasar dan Rujukan). Jakarta; Kemenkes RI; 2013.

10. Fibriana A. The Factors Affecting Maternal Mortality (Faktor-Faktor yang Mempengaruhi Kematian Maternal). Postgraduate Thesis. Semarang: UNDIP; 2007.

11.Luti I, Hasanbasri M, Lazuardi L. Local Government Policy in Improving the Island Region Health Referral System, in Lingga Regency, Riau Islands Province (Kebijakan Pemerintah Daerah dalam Meningkatkan 
Sistem Rujukan Kesehatan Daerah Kepulauan di Kabupaten Lingga Provinsi Kepulauan Riau). Jurnal Kebijakan Kesehatan Indonesia. 2012;01(01):24-35.

12. McCarthy J. A Frame Work for Analyzing the Determinants of Maternal Mortality, Studies in Family Planning. JSTOR. 1992;23(1):23-33. 